\title{
Ecological Sites: Understanding the Landscape
}

\author{
The transition to ecological site descriptions will provide \\ the foundation that will assist land managers in making timely, \\ well informed resource management decisions on \\ rangeland and forest land.
}

By Stan Boltz, Rangeland Management Specialist, Natural Resources Conservation Service, Rapid City, South Dakota and George Peacock, Rangeland Management Specialist, Grazing Lands Technology Institute, Natural Resources Conservation Service, Fort Worth, Texas

$\mathrm{L}$ ooking across any landscape it is not difficult to recognize that some parts are different from other parts in regard to the kinds and amounts of vegetation. Upon noticing these differences, one may ask, "Are these changes random occurrences, or is there a pattern or repeatable entity that can be described?"

As nature would have it, there indeed does exist a relationship. In fact in most cases, an inextricable link between the specific soils on the landscape and the resultant expression of the plants exists. To understand this variation across the landscape, we classify these different parts into units called ecological sites. Landscapes are divided into ecological sites for the purpose of inventory, evaluation, and management.

Any land inventory, analysis, and resulting management decisions require the knowledge of these individual sites and their interrelationships to one another on the landscape. The ecological site description is the document that will contain information about the individual ecological sites.

\section{Why are ecological site descriptions important?}

Range site descriptions have provided ecologically based guidance in making land management decisions for more than 60 years. However, a greater understanding of ecosystem dynamics coupled with an emerging host of new landowners, non-traditional uses, and management objectives has resulted in the transition to ecological site descriptions.

As an evolution of range site descriptions and woodland suitability group descriptions, ecological site descriptions contain information about the ecological dynamics of each site and are used as the standard or reference for resource evaluations and assessments such as trend, similarity index, and rangeland health.
Today, land managers are challenged with synthesizing an overwhelming amount of scientific information concerning soils, hydrology, ecology, management, etc. Ecological site descriptions can serve as a clearinghouse of this information for each ecological site.

\section{What is an ecological site?}

Ecological sites are the subdivisions of forest land and rangeland landscapes which are utilized for inventory and analysis. An ecological site is defined as a distinctive kind of land with specific physical characteristics that differs from other kinds of land in its ability to produce a distinctive kind and amount of vegetation (USDA 1997). Ecological sites evolved from and have replaced range sites and woodland suitability groups.

Each ecological site is the product of all the environmental factors responsible for its development, such as soils, relief or topography, climate, and natural disturbances (fire, herbivory, drought, etc.). Unique associations of plants (plant communities) typically recur when specific environmental factors are repeated across the landscape. An ecological site is recognized and described on the basis of these characteristics and its ability to produce and support a characteristic plant community.

Where changes in soils, aspect, topography or moisture conditions are abrupt, ecological site boundaries are fairly distinct and recognizable. Boundaries are broader and less distinct where ecological sites change gradually along broad environmental gradients of relatively uniform soils and topography.

Although some ecological sites may appear to be along a continuum, distinctive ecological sites can be identified and described. These sites occur with predictable regularity and are associated with concurrent differences in soil, topography, hydrology, or climate. 


\section{What information is contained in an ecologi- cal site description?}

Each ecological site description will contain information about physiographic features, climatic features, soils, associated hydrologic features, and plant communities that occur on the site. Plant community dynamics, annual production estimates, growth curves, associated wildlife communities, and interpretations for use and management of the site are also part of each site description.

The information comprising an ecological site description is presented in four major categories:

- Site Characteristics-Identifies the site and describes the physiographic, climate, soil, and water features associated with the site.

- Plant communities-Describes the ecological dynamics and the common plant communities comprising the various vegetation states. The disturbances that cause a shift from one state to another are also described.

- Site Interpretations-Interpretive information pertinent to the use and management of the site and its related resources.

- Supporting Information-Provides information on sources of information and data utilized in developing the site description and the relationship of the site to other ecological sites.

\section{Describing vegetation dynamics within an ecological site}

In many ways, ecological site descriptions differ from range site descriptions only in format and the additional detail of information contained in the ecological site description. In a traditional range site description, the historic climax plant community was described and a brief paragraph was written about the retrogression of the plant community due to different disturbances.

This brief description gave many the impression that succession is a simple, linear process moving along a continuum between early and late seral or climax. This view of succession did not account for situations that may lie outside of this continuum.

The most significant difference between range site descriptions and ecological site descriptions is the incorporation of concepts related to the state and transition model. While not a new concept, the state and transition model has been more recently looked to as a means to more adequately describe the response of rangeland ecosystems to disturbances. The concept related to state and transition models is designed to address trajectories beyond a simple continuum.

The state and transition model will be utilized in ecological site descriptions to describe the dynamics of vegetation and management interactions associated with

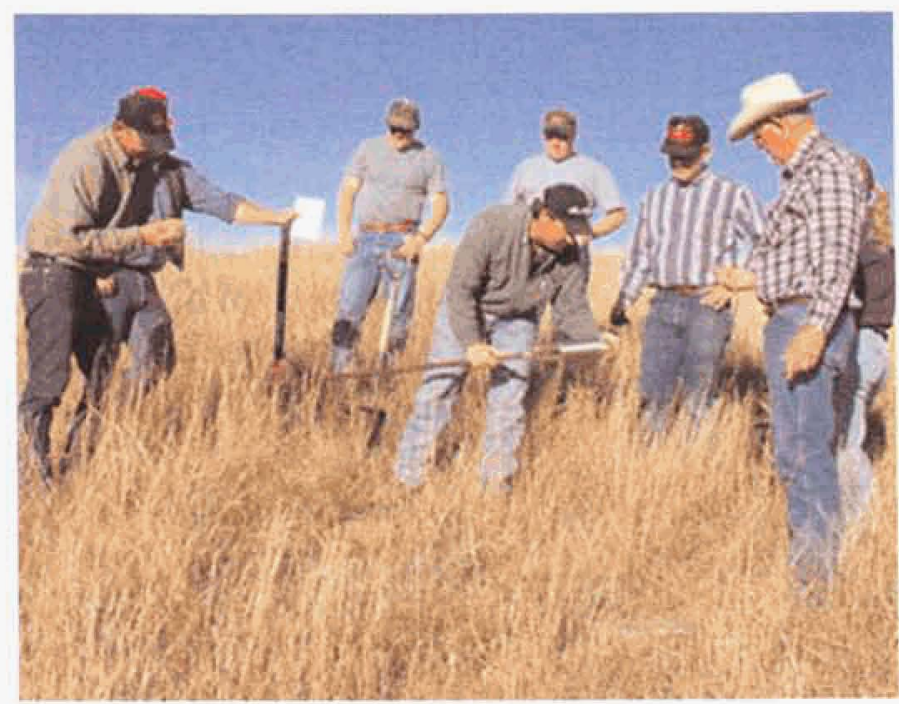

The MLRA 64 local work group conducting soil/site correlation on a Thin Upland ecological site.

each ecological site. Information regarding the different states and plant communities that occur on each site and their response to different types of disturbances will also be included.

Development of a state and transition model involves identifying the different vegetation states that may exist on a site, describing the transitions between these states, and the dynamics that may occur within a state. The state and transition model provides a method to organize and communicate complex information about vegetation responses to disturbances and management.

Figure 1 illustrates the different components of a state and transition model diagram for a Deep Redland Ecological Site in Eastern Edwards Plateau Major Land Resource Area. This Deep Redland ecological site was historically a tall and midgrass savanna with scattered oaks. Periodic fires set by lightning or Native Americans maintained the savanna aspect of the site by removing small woody species. Reduction or elimination of the periodic fires increases the opportunity for encroachment by woody vegetation, primarily Ashe juniper. Once established, juniper encroachment will continue and the transition from State 1 to State 2 has begun.

The transition can be reversed with the reintroduction of fire, through prescribed burning, and implementation of a prescribed grazing management strategy. Prescribed burns should be implemented before Ashe juniper plants exceed four feet in height. This represents a critical decision point for the land manager.

Without any type of management intervention, the transition from State 1 to State 2 will continue until a new equilibrium is established. In this case, a state with a dense canopy of oak and juniper develops, and return to the previous state will be difficult. 


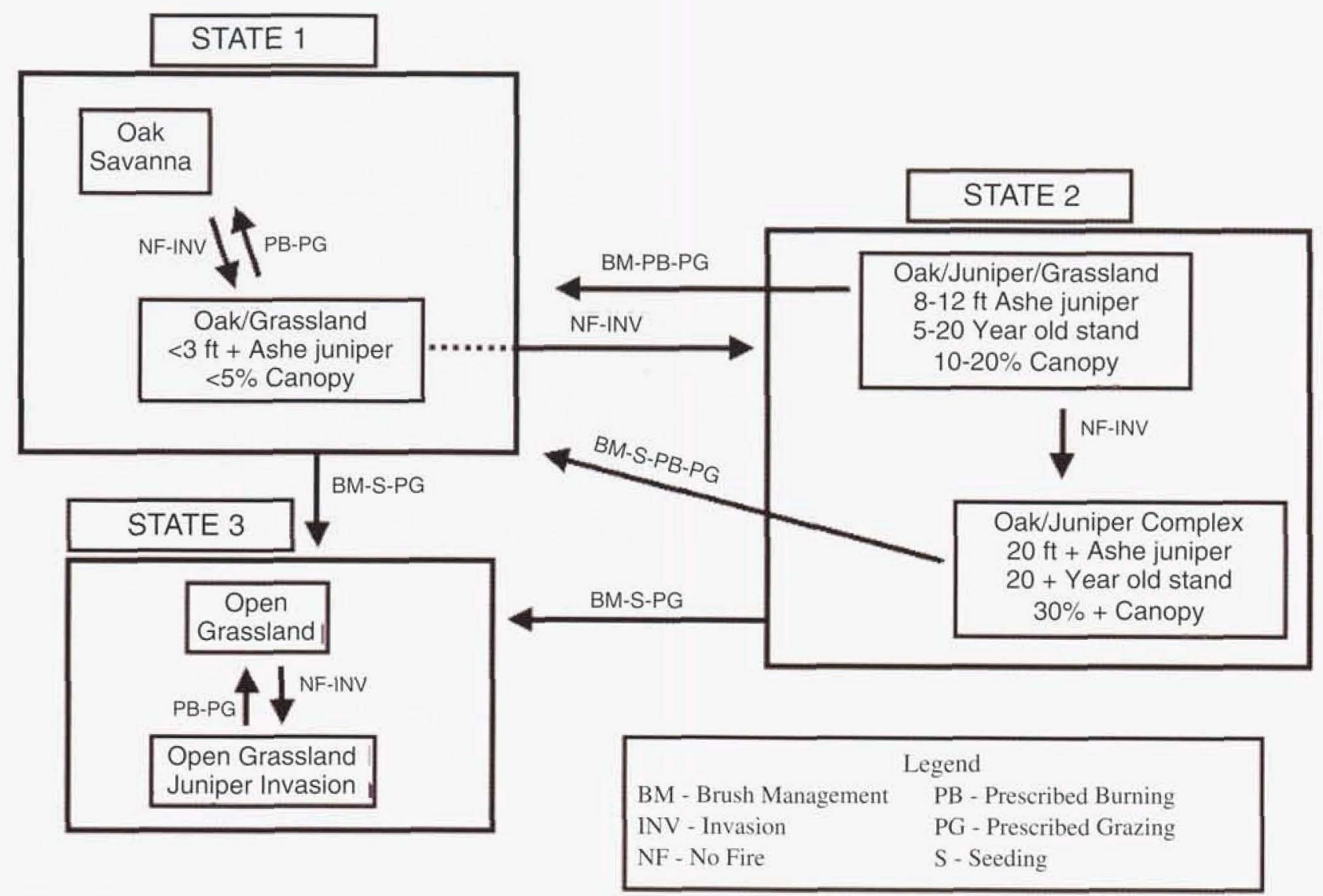

Figure 1. Example state and transition diagram for Deep Redland ecological site description in Eastern Edwards Plateau Major Land Resource Area.

What happens to the primary ecological processes as the size and number of juniper increase? For example, what changes occur in the hydrologic cycle?

- Interception of rainfall by juniper canopy and litter layer under the tree canopy reduces the amount of rainfall reaching the soil surface.

- Bare ground between trees increases due to competition between juniper and herbaceous vegetation for nutrients, sunlight and moisture.

- Increased bare ground results in increased evaporation, runoff and soil erosion from the interspaces.

-The litter layer underneath the juniper intercepts runoff from the interspaces and the increased infiltration rate allows for more rapid uptake of water into soil.

As a result of changes in the hydrologic cycle, total runoff from site may or may not change as transition occurs from State 1 to State 2. However, the amount of water reaching the soil is reduced and water infiltration is redistributed across the site beneath the canopy of the juniper. Return to State 1 is not possible without reestablishing the functioning of the altered ecological processes.

This diagram coupled with the detailed narratives de- scribing the causes of transitions, community pathways and changes in ecological processes comprise the state and transition model. The information contained in this state and transition model provides an excellent communication tool illustrating the interactions among soils, vegetation and management decisions to assist land managers in setting objectives and goals.

\section{How are ecological site descriptions being developed?}

If developing ecological site descriptions were as simple as converting range site descriptions into a new format, the task would likely already be complete. However, the process is not simple, and a substantial effort will be required to complete this task across the country.

One major difference regarding ecological site descriptions is that they will be developed and correlated across entire Major Land Resource Areas (MLRA's). An MLRA is an area that crosses multiple counties and often states, and is characterized by similar soil and landscape characteristics, vegetation, and climate. In the 
past, range site descriptions were developed within each state, and often differences could be found from one side of the state line to the other. Ecological site descriptions will be developed and correlated regardless of political boundaries, and this often requires a great deal of cooperation and communication.

Another factor to consider is that the development of the best possible product requires a joint effort among all organizations, agencies, universities, and others that have interest in or knowledge of the ecological sites. While the development of ecological site descriptions is the ultimate responsibility of the NRCS state range and/or forestry specialists, the broadening scope of the site description to include information regarding other uses and values in addition to traditional uses will require the involvement of discipline specialists other than just range and forestry professionals. Biologists, soil scientists, hydrologists and others both within and outside of NRCS need to be involved in the development process.

Various methods are being utilized to retrieve and assimilate the knowledge and experience that exists for each ecological site. In some cases, an MLRA-wide local work group is being used. These local work groups consist of a relatively small group of people who typically have intimate knowledge of the resource conditions in their respective area. Often the local work group has consisted mainly of range-trained NRCS personnel, but people with other backgrounds both within and outside of NRCS have also been involved.

The focus of these local work groups has been primarily to develop the plant community sections of the ecological site description. Individuals not directly involved with the local work group have largely completed the other sections. In other cases, non-NRCS individuals with vast experience have been consulted to complete entire ecological site descriptions or portions thereof. Some of these include extension and university personnel, or in some cases individuals who are now retired from NRCS or other resource related entities.

Once these drafts are completed, NRCS personnel review and/or complete the other sections, and then the completed site descriptions are available for use. In either case, the development of ecological site descriptions requires a significant commitment. However, the time spent in developing these descriptions also reaps other benefits. First, the ecological site descriptions serve to capture a wealth of knowledge from people who have spent in some cases their whole careers working in and studying these environments. A number of these people have already or soon will retire, and all of that knowledge and experience often leaves with them.

Secondly, the process of developing these descriptions affords many opportunities for younger people to obtain valuable on-the-job training. While the cost of developing ecological site descriptions is relatively high, the value of these and other benefits makes the effort very worthwhile.

The current emphasis is to capture the knowledge that is available at this time. Recognizing that as new information becomes available, the site description can be revised to incorporate new information. The ecological site description should be considered in a continuous state of revision.

Ecological site descriptions provide the foundation that will assist land managers in making timely, well informed resource management decisions on rangeland and forest land.

\section{Ecological site descriptions provide:}

- Information describing the interactions among soils, vegetation, and land management.

- A foundation to assess the condition of current resources and monitor changes.

- A framework to assess management opportunities and predict the outcome of management decisions.

- A framework for identification of knowledge gaps in vegetation dynamics.

- A common framework for communication of resource information among disciplines, agencies and organizations.

- A framework for transferring experience and knowledge.

\section{References}

USDA, Natural Resources Conservation Service, 1997. National Range and Pasture Handbook. U.S. Department of Agriculture, Washington, D.C. 